SECTION 13. Geography. History. Oceanology. Meteorology.

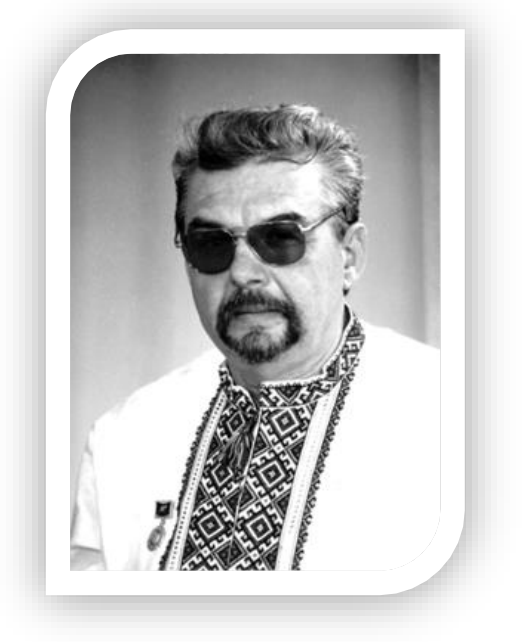

Sergey Iosifovich Tatarinov candidate of historical Sciences, associate Professor, corresponding member of International Academy of Theoretical \& Applied Sciences, Educational and Scientific Professional Pedagogical Institute of Ukrainian Engineering and Pedagogical

Academy

tatbronza@yandex.ua

\title{
THE INTERRELATION OF DISHES WITH SOLAR SIGNS AND PICTOGRAMS AND THE BURIALS IN STONE BOXES OF CARCASS CULTURALLY- HISTORICAL COMMUNITY OF BAKHMUT AREA IN THE DONBAS REGION
}

Abstract: The phenomenon of a large number of clay vessels with solar signs and pictograms in burials of $15^{\text {th }}-13^{\text {th }}$ centuries $B C$ in the copper mines of the Donbas region is discussed in the article. The connection of cup pots on trays with similar Cimmerian copper boilers is supposed there.

Key words: mound, mine, copper, container, icon.

\section{ВЗАИМОСВЯЗЬ ПОСУДЫ С СОЛЯРНЫМИ ЗНАКАМИ И ПИКТОГРАММАМИ С ПОГРЕБЕНИЯМИ В КАМЕННЫХ ЯЩИКАХ СРУБНОЙ КУЛЬТУРНО- ИСТОРИЧЕСКОЙ ОБЩНОСТИ БАХМУТСКОГО КРАЯ В ДОНБАССЕ}

Аннотация: В статье рассматривается феномен большого количества глиняных сосудов с солярными знаками и пиктограммами в погребениях 15-13 веков до н.э. в районе добычи медной руды в Донбассе, предполагается связь кубовидных горшков на поддонах с аналогичными медными котлами киммерийцев.

Ключевые слова: курган, рудник, медь, сосуд, пиктограмма.

УДК 908 (Краеведение)

\section{ВЗАЕМОЗВЯЗОК ПОСУДУ З СОЛЯРНИМИ ЗНАКАМИ ТА ПІКТОГРАММАМИ З ПОХОВАННЯМИ У КАМ'ЯНИХ СКРИНЯХ СРУБНОЇ КУЛЬТУРНО-ІСТОРИЧНОЇ СПІЛЬНОТИ ДОБИ БРОНЗИ У ДОНБАСІ}

Внаслідок багаторічного дослідження автором Донецького гірничометалургійного центру доби бронзи можно говорити по феномен присутності поруч 3 мідними копальнями великої кількості поховань у плитових гробницях-кам'яних ящиках.

Дуже важко застосувати до цієї території виділені Є.М. Чернихом форми соціального статусу майстрів.

Майстри, що обслуговували своє селище, користувалися особливою пошаною, „а кланові організації в більшості були ізгоями суспільства ” [7, 105]. 
В Свропі і на Кавказі майстри були вельми шановані громадами. Шановані ковалі прагнули зберегти таємниці свого ремесла як багатство серед родичів [2].

Ми не знаємо, за винятком 2 поховань на Мосоловському поселенні на Дону [3,c.82], поховань ливарників 3 горщиками і ливарними формами, подібними похованням зрубної культури від Волги до Дніпра і на території Донецького гірничометалургійного центру.

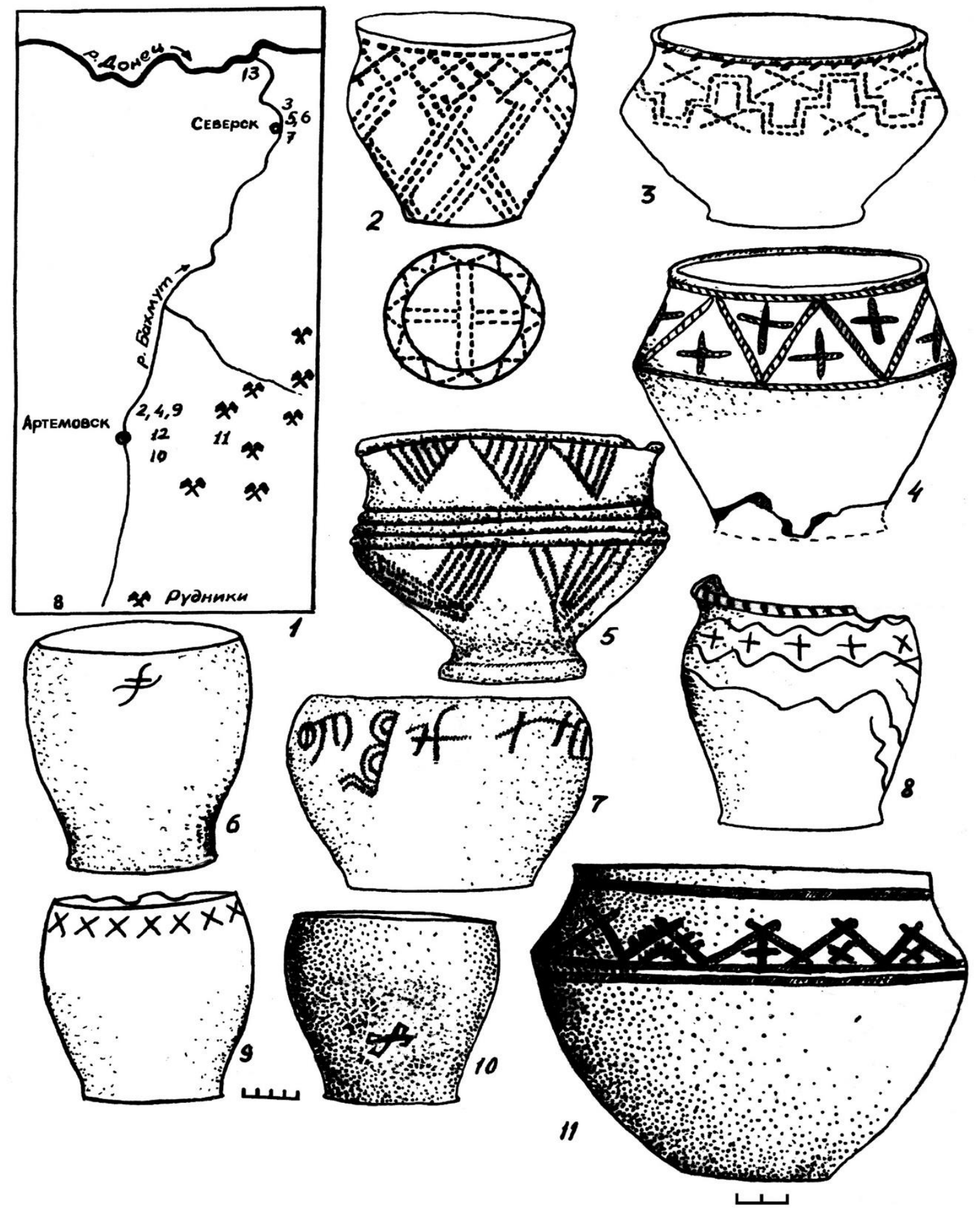

Рисунок 1 - Зрубний посуд з солярними знаками та „написами” з кам'яних скринь: 1-карта розташування поховань зрубної культури з кам'яними скринями біля копалень, 2-9-(за В.О. Городцовим), 10-Весела Долина, к.1.п.1.(1969 р.), 11-Покровське, к.1.п.1, (1970 р.) 
Випадковою є знахідка слідів розораного поховання на Вискрівській копальні у 1979 році, де знайдено разом 3 мідними краплями в культурному шарі північної частини копальні череп і кістки людини, просочені мідним окисом [4,с. 252-255].

Є ритуальне поховання в житлі у Клиновому біля мідної копальні[5,с. 213].

У 2002 році у відвалі біля стволу шахти Червоне Озеро Ю.М. Бровендер відкрив типове поховання зрубної культури з баночним горщиком. Небіжник лежав у скрині, складеній з зелених брил мідістих пісковиків на дні глибокої ями видовбаної у гірській породі [6,с. 28-29].

На Картамиші у підземному штреку Ю.М.Бровендер знайшов поховання ЗК у кам'яній скрині, тобто така форма поховання може бути типовою для гірниківметалургів.

У 1998 році в кургані в 1 км на схід від копалень Кислий Пагорб нами досліджено 2 кам'яні ящики зрубної культури, складені з зелених брил мідних пісковиків, 3 баночними горщиками. Безумовною $\epsilon$ належність цих поховань до гірників-металургів [7].

Скоріше за все, слід вважати масовими похованнями гірників-металургів досить часто присутні біля копалень поховання зрубної культури в курганах 3 кам'яними скринями (рис.1) [8,9 ], де на кераміці завжди є символи вогню - косі хрести, фестони, свастики, складні „письмена” [10-11].

Цікаві спостереження про зв'язок бронзових казанів так званого «кіммерійського типу» зробили В.В. Отрощенко та М.П. Тупчієнко, які пов'язують концентрацію глиняного посуду кубоподібних форм зрубної культури - „зона максимального поширення кубків накладається на Донецький гірничо-металургійний центр і такий збіг навряд чи можливо вважати випадковим, ...виготовлення казанів на конічному піддоні у Донецькому гірничо-металургійному центрі дістає логічних підстав, ...виготовлення казанів припиняється із завершенням функціонування Донецького гірничо-металургійного центру на початку XII ст. до н.е.” [12,c. 181].

3 мідними копальнями можуть бути пов'язані комплекси поховань вождіввоїнів катакомбної культури 3 булавами, наборами наконечників стріл 3 кременю 3 „вусиками”, випрямлювачами держаків стріл і різноманітним металом досліджені у 1990 - 1998 роках біля Артемівська. [7,с. 143-153; 9;13].

Якщо у Придніпров'ї, за І.Ф.Ковальовою, підкурганні поховання енеолітичного типу є віддзеркаленням у похоронному обряді професійної спеціалізації померлих 3 ковальсько-ливарними інструментами, то їх відсутність у зрубників Є.М. Черних пояснює, виходячи з соціального статусу майстрів гірників-металургів і ковалів, існуванням особливих поховальних ритуалів - „рівно як і відокремлених цвинтарів у групах майстрів" [7,с. 166].

До подібних кладовищ біля копалень або поблизу від них можна віднести Володимирівські (1978р.), Пилипчатинсько-Покровські (1998р.), Артемівські (1970 1996 рр.), Відродженські (1984 - 1985 рр.) [9] кургани, де знайдено понад 30 кам’яних ящиків зрубної культури. Ці поховання підковою охоплюють Бахмутські копальні.

Відособленню поховань майстрів служили релігійні уявлення щодо їхної професії, оточеної цілою системою найсуворіших табу [1,c. 159].

В.М. Массон [14,с. 67] писав про релігійні уявлення, де формується божественне походження металургів-ковалів, попередників Гефеста в Європі, де відзначено за етнографічними даними наявність обряду передачі „сили управління вогнем”, яка приписувалася гірникам - металургам при плавці металу [1,с. 140].

А.Д. Пряхін описує відкрите у 1978 році на Мосоловському поселенні поховання в котловані житла, де кістки людини виявилися складеними купкою, поряд горщик і ливарна форма [15]. 


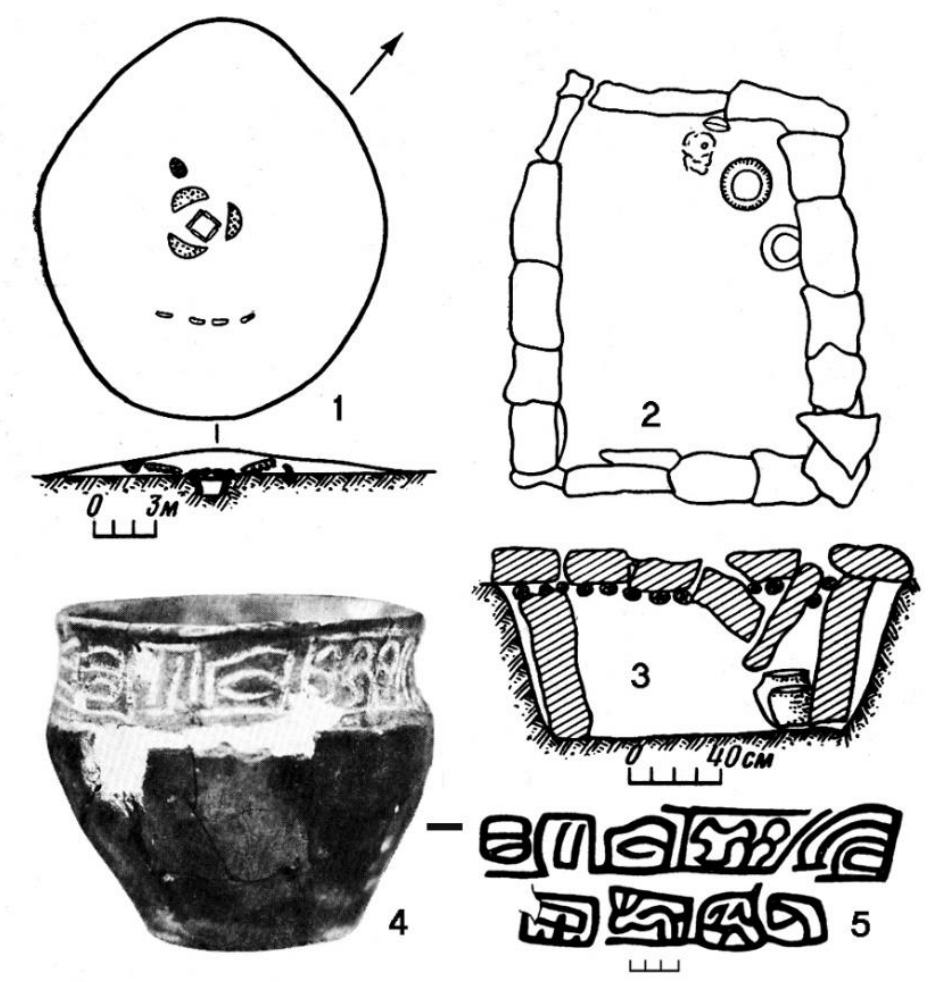

\section{Рисунок 2 - Артемівськ, к.1.п.1 - 1-3-поховання зрубної культури у кам'яній скрині, 4-5-кубок 3 ,написом” (1972 р.)}

В Центральній Азії були поширені повір'я про цілющу силу і добродійні знання ковалів. В Африці етнографи у XIX сторіччі відмічали, за словами аборигенів, що ковалі клали в печі шматочки людського тіла. В багатьох районах Америки ковалі користувалися великою пошаною, їх магічній силі підкорялися метали [16,с. 66].

Останнє зауваження до того, чи суворо охороняли майстри (клани) зрубної культури свої копальні. Присутність на ряді поселень, як ми неодноразово відзначали, синкретичної кераміки (Пилипчатине - від бабинської, зрубної, федорівськочеркаскульської до сабатинівської та білозерської; Клинове - зрубної, сабатинівської, білозерської і ранньої бондарихинської) свідчить проти того, що копальні були суворо утаємничені. Швидше за все, клани залучали і допускали до видобутку руди представників близьких етнічних груп; відносини навколо копалень між племінними групами Північного Причорномор'я носили мирний характер.

\section{References:}

1. Chernyih E.N. Drevnyaya metalloobrabotka na Yugo-Zapade SSSR/E.N.Chernyih//.M.: Nauka, 1976.- 302 s.

2. Teylor E. Pervobyitnaya kultura /E.Teylor//.- M., 1939.- $560 \mathrm{~s}$.

3. Pryahin A.D. Mosolovskoe poselenie metallurgov-liteyschikov epohi pozdney bronzyi: Kniga vtoraya.- Voronezh: Izd-vo VGU, 1996.- 176 s.

4. Tatarinov Drevniy mednyiy rudnik ,Vyiskrivskiy” v Donetskoy oblasti/ Tatarinov S.I. // Sovetskaya arheologiya.- M., 1978.- \#4.- S. 251-255.

5. Tatarinov S.I. Zhilische gornyakov bronzovogo veka na Klinovskom mednom rudnike v Donbasse" /Tatarinov S.I. // Arheologicheskiy almanah.- Donetsk, 2002.- \#10.- S.209-214.

6. Brovender Yu.M. Kartamyishskiy proizvodstvennyiy kompleks gornometallurgicheskogo tsentra epohi pozdney bronzyi (nekotoryie itogi issledovaniy) 
/Yu.M.Brovender // Problemi gIrnichoYi arheologIYi (dopovIdI II-go mIzhnarodnogo Kartamiskogo polovogo arheologIchnogo semInaru).- Alchevsk: DGMI, 2003.- S. 22-35.

7. Kravets D.P., Tatarinov S.I., Fedyaev S.V. Kurganyi donetskoy katakombnoy kulturyi v urochische „Ostraya mogila” (Donetskaya oblast) /D.P.Kravets // StarozhitnostI stepovogo Prichornomor'ya I Krimu.- ZaporIzhzhya, 2000.- Vip. VIII.- S.143-153.

8. Tatarinov S.Y., Kravets D.P. NaydavnIshI metalurgi UkraYini /S.Y.Tatarinov // Bahmutskiy chasopis.- Artemovsk, 1995.- \# 3-4.- S. 5-12.

9. Litvinenko R.A. Kurgannyiy mogilnik Vozrozhdenie II na Donetchine /R.A.Litvinenko// Rossiyskaya arheologiya.- M., 1993.- \#3.- S.188-197.

10. Tatarinov S.I. Novyie sosudyi epohi bronzyi so znakami (Donbass) /S.I.Tatarinov// Sovetskaya arheologiya.- M.,1981.- \#4.- S. 250-253.

11. Tatarinov S.I. Kosmogonicheskie predstavleniya lyudey epohi bronzyi /S.I.Tatarinov// Byiloe.- Artemovsk, 1991.- \#1.- S. 4-6.

12. Otroschenko V.V., TupchIEnko M.P. BronzovI klepanI kazani ta Donetskiy gIrnichometalurgIyniy tsentr /V.V.Otroschenko // Problemi gIrnichoYi arheologIYi (materIali II-go mIzhnarodnogo Kartamiskogo polovogo arheologIchnogo semInaru).- Alchevsk: DonDTU, 2005.- S. 176-184.

13. Kravets D.P., Tatarinov S.I. Novyie katakombnyie pamyatniki Bahmutskogo kraya/D.P.Kravets // Donetskiy arheologicheskiy sbornik.- Donetsk, 1997.- Vyip. 7.- S. 77116.

14. Masson V.M. Ekonomika i sotsialnyiy stroy drevnih obschestv/V.M.Masson//.- L., 1976.- 193 s.

15. Pryahin A.D., Ekimov Yu.G., Matveev Yu.P., Startseva T.S. Issledovaniya pamyatnikov pozdney bronzyi v lesostepnom Podone /A.D.Pryahin // AO 1978 goda.- M., 1979.- S. 82.

16. Forbes R.J. A notebook for archaeologists and technologists.- Leiden, 1950. 